\title{
National Identity in China - Contribution from the Beijing Olympic Games? A Survey among Residents of Beijing
}

\author{
Xiaoping Ying ${ }^{1}$, Arnulf Kolstad ${ }^{2}$ \& Yiyin Yang ${ }^{1}$ \\ ${ }^{1}$ Chinese Academy of Social Sciences (CASS), Beijing, China \\ ${ }^{2}$ Nesna University College, Nesna, Norway \\ Correspondence: Arnulf Kolstad, Nesna University College, 8700 Nesna, Norway. Tel: 47-9133-7205. E-mail: \\ arnkol@alumni.ntnu.no
}

Received: April 3, 2013 Accepted: June 7, 2013 Online Published: August 30, 2013

doi:10.5539/ass.v9n11p7 URL: http://dx.doi.org/10.5539/ass.v9n11p7

\begin{abstract}
This article is dealing with the consequences of Beijing 2000 Olympic Games for the host city population and focuses primarily on three areas of expectations and impact: (1) On China's international reputation; (2) On enhancing national pride, social and national identity, and (3) On the impact on the "individual self" and how BOG may give personal benefits. To separate the consequences in this way, between the impact on "international", "national," and "personal" matters, is particularly interesting in a collectivistic or interdependent culture such as traditional China. Nearly 1000 residents of Beijing have filled in a questionnaire or been interviewed. The sampling technique was a combination of quota and random sampling. The results showed that the international influence is expected to be significantly greater than the national governmental influence, and greater than the influence on the common people as a group. Older residents of Beijing focused significantly more than the younger residents on the international and national consequences, whereas the younger generation focused more on individual consequences and personal benefits. The great majority of the respondents expect the Beijing Olympics to enhance China's reputation internationally and improve international relations. The support and expectations from the Chinese people for utilizing the Beijing Olympics as an instrument to reach such goals and to promote international cooperation are stronger than in other host cities and countries.
\end{abstract}

Keywords: Olympic Games, China, national identity, personal benefits

\section{Introduction}

This article aims to identify, review, and examine the host city residents' perceptions of expected impacts from the Beijing 2008 Olympic Games (BOG). We focused on what the Chinese looked forward to and expected to happen for the nation, for the Chinese people, and for themselves. The expectations were coloured by the immense positive prospects among the Chinese toward the Games. The whole nation was enthusiastically behind Beijing's application for hosting the 2008 Games. Zhou \& Ap (2009) documented that over 95\% of the Beijing residents supported the Games. The Beijing Olympic Bid Committee claimed a 94.9\% public support in Beijing (Tang, 2001: 13), whereas the International Olympic Committee's (IOC) poll showed a 96\% support in urban areas (IOC, 2001: 60), illustrating a significant public support for the prospect of organizing the Beijing Games. Previous studies among other host city residents have also revealed great enthusiasm and support for the Olympic Games, but never to the same extent as among the Beijing residents (Karakatsoulis, Michalopoulus \& Moustakatou, 2005; Waitt, 2003).

Mega events such as modern Olympic Games have the potential to influence the host nation and its inhabitants in many ways. The residents of the host city have expectations about benefits for their nation, their city, as well for their families and themselves as individuals. This study focuses primarily on three areas of expectations and impact: (1) On China's international reputation and how the country and its culture is evaluated abroad, which is termed "international consequences"; (2) On China as a nation, enhancing national pride, social and national identity, and support of the government. This factor, called "national consequences," is divided in two categories: (a) consequences for the government, the State, and the organized China; and (b) consequences for the Chinese people, especially the "common people" - the majority of the Chinese who most residents in Beijing feel affiliated to; (3) On the individual or "private" Chinese, the impact on the "individual self" and how BOG may give personal benefits to themselves and others. To separate the consequences in this way, between the impact on 
"international", "national," and "personal" matters, is particularly interesting in a collectivistic or interdependent culture such as traditional China (Triandis, 1993). It also reveals something about the strength and relationships of "social identity" and "individual identity" in such cultures.

\subsection{International Reputation}

A main reason for the enthusiasm among the Chinese was according to IOC, the "feeling that a successful bid would bring recognition to the nation." This attitude toward hosting and participating in the Olympic Games is not unique. It represents what most countries that participate in the Olympic Games aim for. In particular, the nations hosting the Olympics have a unique opportunity to position the host city and the country to a global audience (Singh \& Hu, 2008), to be known and recognized, and to show the whole world their capabilities (Ikhioya, 2001). The gains from hosting the Games include increased goodwill toward the host nation, enhanced political influence abroad, and increased prestige in the eyes of the world (Johnston, 1985; Ritchie \& Lyons, 1990). Success in hosting the Olympics affords opportunities for nations to be identified in terms of international awareness and recognition in building international confidence, friendships, and cooperation. To raise the host nation's international status has therefore been an important goal in former Olympic Games. Previous studies have shown that governments and inhabitants in host countries pay a lot of attention to how the host nation is assessed by other nations and by the international society (Karakatsoulis, Michalopoulus \& Moustakatou, 2005, Waitt, 2003). The positive international exposure boosts the host populations' national identity, national pride, and patriotism (Calgary Report, 1988; Johnston, 1985; Ritchie \& Lyons, 1990). The great enthusiasm in the host city populations for promoting their country has been well documented. Shortly after Sydney's successful bid for the 2000 Olympics, Australian Prime Minister Paul Keating announced, for instance, that this "was a major step in Australia's search for a new international identity" (Cashman, 2006).

To be accepted as a great nation abroad and to raise the country's international reputation and status most often also enhance the national feelings and support for the government at home. The pride of belonging to a nation recognized by the rest of the world as great and prosperous stimulates social or national identity. Hosting the Games therefore ignites feelings of national pride and nationalism (Waitt, 2003). The two aims are most often combined and the positive relationship between international recognition and national feelings or national identity has been documented in most host countries recently.

\subsection{National Identity, Support, and Pride}

The international reputation is therefore not the only reason for the popularity of becoming the host of the Games. Olympic Games also help in fostering feelings of national pride and national identity among people in the host country (Karkatsoulis, Michalopoulus \& Moustakatou, 2005; Powers, 2004; Evans \& Kelley, 2002).

The issue of national identity has been developed through a range of social theories. It involves feeling proud to be the national of a particular country, appreciating the nation's problems, taking personal pride and joy in achievements, introducing oneself openly as a national, and encouraging friends and close acquaintances to see one's country in a positive light (Matthew et al., 2000). When talking about national identity, we are talking about the individual's sense of belonging to the nation, the self-association with the success of the nation. The Olympic Games provide, according to Ikhioya (2001), an ideal vehicle for the projection of national identity and boosts the host countries inhabitants' national confidence and pride, as it happened, for instance, before the Barcelona 1992 Games (Hargreaves \& Ferrando, 1997) and it was also what mainly motivated the Greeks (people, government, organisers and volunteers) to successfully organize the Athens 2000 Olympics (Powers, 2004).

National identity is expressed by national pride. In Norway, the pride of being a Norwegian increased significantly from before to after the Lillehammer 1994 Winter Games. Before the Games, $79 \%$ of the population expressed pride in being a Norwegian, 4 weeks after the Games, $88 \%$ expressed their pride (Kolstad, 1995). Successfully hosting the Olympic Games and sporting success during the Games bring credit and prestige to the country and enhance national pride (Evans \& Kelley, 2002).

International sport events have a particular contribution to national pride and to national identity, and governments increasingly recognize the capacity of sport (Olympic Games especially) to promote a sense of national identity (Ikhioya, 2001; Houlihan, 1997; Maguire, 1993). The Olympic Games have definitely become a central stage to present and promote national identity, tradition, and culture for the host country (Xin, 2006). At the Sydney 2000 Olympics, "this was illustrated by the fact that community and national spirit" and "international promotion" were the most powerful rewards for many Australians (Waitt, 2003). Successes in the Olympics instil credibility to national governments, and increase sense of belonging and identity among the populace. 
Many event organizers have experienced that the Olympic Games can act as a catalyst to promote an increased sense of national identity. The contemporary opening ceremony plays an important role in the re-packaging of a national identity for both local and international consumption. Identity and community cohesion are important subjects as political leaders tout them as benefits, both before and after the event.

The national identity promoted by the Olympic Games and International sports in general is not the one promoting hostility and conflicts between nations (Hobsbawm, 1990). It more often promotes solidarity within the nation (Colley, 1992), without antagonism toward the outer world. Nationality becomes a basis of mutual obligation and social solidarity: one feels obligated to one's fellow nationals. Such shared national sentiment can also provide a basis for the legitimacy of the state (Verba, 1965). A shared national identity is definitely a social "glue that holds a nation together" (Smith \& Jarkko, 1998). It has been said that the true legacy of the Olympic Games is the sense of accomplishment and pride it creates among the citizens (Powers, 2004).

According to Zhou (2008), the Chinese governments' primary motivations to host the BOG were to showcase its reform achievements to the international community, as well as to unify its citizens, boost nationalism, and increase cultural exchange with other countries. It is expected that international promotion and enhanced national pride and support are important goals for the Chinese as well and we would therefore expect that those who paid attention to the Beijing Olympics' influence on China's international status also paid attention to its importance for enhancing the reputation of the nation and the support of government at home.

\subsection{Personal Benefits}

Hosting the Olympic Games also gives the inhabitants an opportunity to make money themselves or to have other personal benefits. Especially in independent and competing cultures, the people are requested and used to make their own living, to see the possibilities for themselves, and to gain some benefits. In the Western world, people have started their own business and earned money during the games, others have got well-paid jobs during the games in companies and organizations related to the event, and others have enjoyed the opportunity of meeting people from abroad and also the joy of watching the sports and cultural events live as spectators. We asked the Beijing respondents about the importance of such personal or individual benefits, for instance, to what degree they agreed or disagreed in items like: The Beijing Olympics "provides me with the opportunity to make money," "I have the opportunity of improving my own abilities," and "I have the opportunity to see lots of bustling things happen." It is expected that respondents paying much attention to consequences such as these look forward to gain personal benefits from BOG, and in this way, strengthen their personal identity to a greater extent than their social or national identity.

\subsection{Collectivism and Individualism}

In an interdependent and collectivistic culture like China, the achievement of the nation and its people is often more important than individual, private success. What is good for China is good for its population, even if it does not give personal benefits in terms of improved economic conditions. The Chinese are modest, humble, and unassuming, and they have the ability to be happy and satisfied even when their material living conditions are much lower than in the wealthy Western world. They become happy on behalf of their country if it is evaluated as a successful and able nation. This is expected to be a major motivation for the enthusiasm of BOG among the Chinese.

Little research has been conducted revealing more in detail what the local residents pay special attention to or what they, in particular, expect from the games concerning the importance for the nation, for its inhabitants, and for each individual. It was assumed that the Chinese looked at BOG as something influencing the international, the national, and the personal: (1) enhancing China's reputation abroad and promoting international cooperation, (2) strengthening China and its government, and (3) also bringing personal benefits to the Chinese people. In this article, we therefore focused on these three consequences to see which one did the Beijing respondents emphasize most when looking forward to BOG.

There are, of course, different expectations: Some people looked forward to the competition among the athletes, others paid more attention to the cultural celebration, exhibiting the host country's culture and traditions; others again looked at the Olympic games as a vehicle for nationalism and patriotism; and some emphasized the opportunities of personal gains, for instance, to earn money during the Games. Our aim was to reveal the relative strength of the three different, but related, consequences.

Special attention in this study was paid to the expectations among different groups of Chinese, especially between those who are most influenced by the traditional Chinese culture, its values and norms, and those more influenced by "modernization," individualization, and other Western values and ideals. Differences in 
expectations due to age (cohorts) are therefore reviewed and discussed. Taking China's history into consideration, it is expected that the older generation pay more attention to the international reputation and national support while the younger generation, to a larger extent, emphasizes personal benefits and individual opportunities.

\section{Method}

\subsection{The Sample}

The sampling technique is a combination of quota and random sampling. Beijing is, according to the administrative system in China, separated in 16 districts. Four of the 16 districts were selected and data were collected in communities or street units representing different populations according to type of house, age, income, and education (see Table 1). The total valid sample is 962 .

Table 1. Sample distribution and characteristics

\begin{tabular}{|c|c|c|c|c|c|c|}
\hline Code & District & House type/standard & $\begin{array}{l}\text { Age } \\
\text { group }\end{array}$ & Income/Education & $\begin{array}{l}\text { Estimated } \\
\text { sample }\end{array}$ & $\begin{array}{l}\text { Valid sample } \\
(N=962)\end{array}$ \\
\hline $\mathrm{H}$ & Dongcheng & $\begin{array}{l}\text { Old life style, } \\
\text { apartment buildings }\end{array}$ & Elder & Low & 100 & 85 \\
\hline $\mathrm{J}$ & Dongcheng & $\begin{array}{l}\text { Old life style, } \\
\text { traditional Hutongs }\end{array}$ & Elder & Low & 200 & 208 \\
\hline $\mathrm{C}$ & Chongwen & Medium standard & $\begin{array}{l}\text { All age } \\
\text { groups }\end{array}$ & Middle & 200 & 200 \\
\hline $\mathrm{F}$ & Chongwen & $\begin{array}{l}\text { Medium/high } \\
\text { standard }\end{array}$ & $\begin{array}{l}\text { All age } \\
\text { groups }\end{array}$ & Middle/High & 200 & 181 \\
\hline G & Shijingshan & $\begin{array}{l}\text { Old village in city*. } \\
\text { Low standard }\end{array}$ & $\begin{array}{l}\text { All age } \\
\text { groups }\end{array}$ & Low & 100 & 190 \\
\hline $\mathrm{L}$ & Changping & High standard & Young & High & 200 & 98 \\
\hline
\end{tabular}

* This community consisted primarily of former farmers who today were immigrant workers.

In Community F, there are, for example, 2540 households and 5835 inhabitants. Seven hundred thirty belong to the mobile population not permanently living in Beijing. Of the 2540 households in this community, 200 were selected randomly to be included in the sample.

\subsection{The Procedure}

The questionnaire survey among Beijing residents was carried out in March and April 2008, 5 months ahead of the Games. Respondents were visited in their homes by research assistants and were asked to take part in the survey. Within a household, the last or next birthday method was used to select a respondent. Age inclusion criterion was over 18 and less than 70 .

In some cases, when the respondent did not read very well, or had reduced vision, the questionnaire was filled in like an interview. The research assistant read the questions and marked the answers. Of the 962 accepted questionnaires, 591 were filled in by the respondent; 121 questionnaires were filled in by the respondent with some explanations from the research assistant; in 129 cases, the research assistant read the questions and the respondent marked for the answer; and in 121 cases, the research assistant read the questions and marked the answer.

The questionnaire contained altogether 300 questions. Some questions dealt with the expected influence of the Games on China as a nation, its culture and politics, the inhabitants' personal life, and how people from other nations were appreciated. This paper focuses on Beijing residents' expectations concerning BOG's international, national, and personal consequences which includes 25 items.

The questionnaire data were cleaned according to accepted procedures and the effective sample was reduced from 1050 to 962 . The reasons for withdrawal of questionnaires are shown below:

Questionnaires delivered 1050 
Questionnaires returned 1040

Questionnaires accepted after first check

Questionnaires in the data file 990

After checking the data file by sight $\quad 981$

After checking for biased and logical errors

\subsection{Sample Characteristics}

Sex. Male, $42.5 \%$; female, $55.8 \%$; the rest did not state gender.

Age. Of the sample of $962,54.1 \%$ was born before $1970,45.7 \%$ in 1970 or after $(0.2 \%$ did not give their year of birth).

\section{Results}

\subsection{International and National Consequences}

The respondents have marked how the Beijing Olympic Games may influence stated items using a 4-point Likert scale ( $1=$ no influence; $2=$ little influence; $3=$ some influence; $4=$ huge influence). (Those answering "not sure" were not included.) The items were classified into two categories whether they are related to (1) international reputation or affairs (4 items); (2) the Chinese nation [this category is further divided into two: (a) with focus on the government, state, and formal organizations (4 items), and (b) consequences for the Chinese common people (7 items)]. ("Common people" is a phrase often used in China for people not in power, who are not leaders or have long education. Most of the respondents in the study belong to "common people"). The items representing the consequences of BOG being expected to influence on national or international affairs are presented in Table 2 .

Table 2. Items representing international or national influences (Cronbach $\alpha, \mathrm{N}$ and Mean)

Reliability

\section{International influence}

Raise China's international status

Promote international cooperation

Promote common people's willingness to learn more about other countries

$\alpha=0.760$

$N=898$

Encourage foreigners to understand China's assets

\section{National influence (on Government, State, Organizations)}

Strengthen the country by enhancing people's participation in national events

Improve the efficiency of the Chinese government

$\alpha=0.797$

Promote the importance of non-governmental organizations (such as charity, green movement)

Strengthen the overall development of China's society and economy

\section{National influence (on Chinese common people)}

The Olympic Games will result in economic benefits for common people

Improve common people's living situation

Enhance the people's emphasizes on health and exercise

$\alpha=0.889$

Improve public manners (for instance, waiting in lines, helping each other, courtesy, etc.)

Contribute to the Chinese people's accept of the idea of winning through competition

Increase the Chinese people's demand of learning more about their own culture and history

Bring more benefits to the common people

Cronbach $\alpha$ for items representing international and national issues are $0.76,0.80$, and 0.89 , respectively. The consistency of items within international and national issues is high. There are significant differences between the means for all three categories (Table 3). 
Table 3. Differences in mean between the international and national influences $(t$-test)

\begin{tabular}{|c|c|c|c|c|}
\hline & & t-test & $\mathrm{N}$ & $\mathrm{p}$ \\
\hline \multirow[t]{2}{*}{ Pair 1} & International Influence - National Government Influence & 9.796 & 955 & .000 \\
\hline & $\mathrm{M}=3.4898, \mathrm{SD}=.568 \quad-\quad \mathrm{M}=3.3612, \mathrm{SD}=.637$ & & & \\
\hline \multirow[t]{2}{*}{ Pair 2} & - National People Influence & 16.865 & 956 & .000 \\
\hline & $\mathrm{M}=3.4876, \mathrm{SD}=.572 \quad-$ & & & \\
\hline \multirow[t]{2}{*}{ Pair 3} & National Government Influence - National People Influence & 10.002 & 956 & .000 \\
\hline & $\mathrm{M}=3.3624, \mathrm{SD}=.637$ & & & \\
\hline
\end{tabular}

The international influence $(M=3.49)$ is expected to be significantly greater than the national governmental influence $(M=3.37)$, and greater than the influence on the common people as a group $(M=3.22)$. The influence on the government is expected to be greater than the influence on the common people's situation. The results can be expressed as international influence $>$ national influence (government) $>$ national influence (common people).

\subsection{National or Individual Focus}

The respondents also marked to what degree they agree or disagree in items representing two categories of statements: one expressing a national focus (4 items), the other representing an individual or personal focus (6 items). Agreement was expressed on a 4-point Likert scale (1=totally disagree; $2=$ disagree; $3=$ agree; $4=$ totally agree). Table 4 gives the Cronbach $\alpha$ and mean for the items in each category and also the $t$-test for differences between the two categories.

Table 4. Individual and national focus (Cronbach $\alpha, M, t$-test, and $p$ )

\begin{tabular}{|c|c|c|c|}
\hline & Reliability & Mean & $t$-test \\
\hline National Focus & \multirow{5}{*}{$\begin{array}{l}\alpha=0.802 \\
N=844\end{array}$} & \multirow{5}{*}{2.8301} & \multirow{12}{*}{$\begin{array}{l}t=23.538 \\
N=954 \\
p=.000\end{array}$} \\
\hline I have the opportunity to show happy and healthy Chinese & & & \\
\hline I have the opportunity to contribute to a big Chinese event & & & \\
\hline I have the opportunity to cheer for the Chinese athletes at the sites & & & \\
\hline $\begin{array}{l}\text { I have the opportunity to bask in the reflected glory of Chinese athletes } \\
\text { winning the gold medal in close distance on sites }\end{array}$ & & & \\
\hline Individual Focus & & & \\
\hline I have the opportunity of improving my own abilities & & \multirow{6}{*}{2.4201} & \\
\hline It provides me with the opportunity to make money & & & \\
\hline I have the opportunity to display my talents & $\alpha=0.762$ & & \\
\hline I have the opportunity to have a once-in-a-life experience & $\mathrm{N}=785$ & & \\
\hline I have the opportunity to enjoy on close range high-level sport events & & & \\
\hline I have the opportunity to see lots of bustling things happen & & & \\
\hline
\end{tabular}

Cronbach alphas for the national and the individual focus are 0.80 and 0.76 , respectively. The national focus is significantly more important $(M=2.83)$ than the individual focus $(M=2.42)$. National focus represents the Chinese people's interests as a group, not what they could get from BOG as single individuals. The Games in Beijing was expected to have a greater impact and be more important for social or national identity than for private, individual life and personal identity. This can be expressed as national focus $>$ individual focus.

Differences in international, national, and individual expectations from BOG due to age (cohorts) are presented in Table 5. 
Table 5. Expected international, national, and individual consequences according to the old and young generation in Beijing (means, $t$-test)

\begin{tabular}{lllllll}
\hline & Old (1938-1950) & \multicolumn{2}{c}{ Young (1970-1990) } & \multirow{2}{*}{$p$} \\
& Mean (SD) & $N$ & Mean (SD) & $N$ & & \\
\hline International Influence & $3.5921(.51004)$ & 143 & $3.4351(.56651)$ & 434 & 3.103 & $.002^{* *}$ \\
National Government Influence & $3.5082(.54603)$ & 143 & $3.2519(.65115)$ & 433 & 4.239 & $.000^{* * *}$ \\
National People Influence & $3.3760(.60421)$ & 143 & $3.0854(.68015)$ & 434 & 4.551 & $.000^{* * *}$ \\
National Focus & $2.5804(.83288)$ & 142 & $2.8497(.78211)$ & 433 & -3.393 & $.001^{* *}$ \\
Individual Focus & $2.2081(.67735)$ & 142 & $2.4267(.6635)$ & 435 & -3.357 & $.001^{* *}$ \\
\hline
\end{tabular}

The older residents of Beijing focused significantly more than the younger residents on the international and national consequences, whereas the younger generation in the capital focused more on individual consequences and personal benefits.

\section{Discussions and Conclusions}

\subsection{International, National, and Individual Consequences}

Comparing the international and national consequences of the Beijing Olympics, the residents of Beijing pay most attention to China's international reputation and how the nation is looked upon by the foreigners (Table 3). They focus less on the national consequences whether it is for the government or for the population and common people inside China. When national consequences and individual consequences are compared, Beijing residents emphasize national consequences more than the individual consequences or the private benefits (Table 4). This does not mean that BOG is not important for the Chinese. In a collectivistic culture such as China, what happens with the nation and how it is perceived by others is often more important than individual benefits. To promote China at the international arena and make the "motherland" a respectable and strong country in the world is more significant for most Chinese than to get personal gains. The Games is looked upon as an important vehicle to achieve pride through social identity and being a member of the great nation China. Personal or private benefits are not expected from the Games to the same degree, and the personal identity does not seem as important as the national identity. In an interdependent or collectivistic culture such as China, a joint social identity is more important than in individualistic or independent cultures such as the ones in the West.

The Chinese is said to have the boundary-permeated self-construal that can expand or contract depending on the context and social influence (Yang, et al., 2010). The Chinese people develop, in their traditional culture, a contextual elastic self with the ability to include their fellow countrymen as well as the nation in their selves. For instance, in situations that activate patriotism, participants' self-construal is arguably expanded to the national level; the nation is contained within the self and becomes part of the "me" appraisal. The individuals do not feel themselves outside the nation but perceive their selves as part of the nation and the nation as part of themselves. In other words, the individual self and the nation are united into one psychological entity. Indeed, Confucius teaching in Chinese culture points out that the higher permeability of the self boundary is, the more superior the individual is in morality. That is, the Chinese, heavily influenced by Confucius teaching and philosophy, are motivated to include the family, the nation, and the world into their selves. The Beijing Olympics is an international as well as a national and personal event, and the different selves will be influenced by the event. The results in this study show that the international self is most often activated by BOG, then the national, and least the individual self.

The boundary-permeated self-construal peculiar to the Chinese people plays an important role in this process and can explain how the often said contradiction between individualism and collectivism is handled by the Chinese people (Yang et al, 2010).

\subsection{Raise China's International Reputation}

Most countries hosting the Olympic Games have used the event as an opportunity to promote the nation, its traditions, benefits and qualities, and China is definitely no exception. The great majority of the respondents expect the Beijing Olympics to enhance China's reputation internationally and improve international relations. The support and expectations from the Chinese people for utilizing the Beijing Olympics as an instrument to reach such goals and to promote international cooperation are, however, stronger than in other host cities and countries. By hosting the Games, billions of people outside China will be aware of the country. This is important 
for most Chinese since many have the impression of not being fairly evaluated by the rest of the world, especially in the West. There are some historical and political reasons for this. The enthusiasm among the Chinese to show the world that China is a great nation and able to host successful Games, and in this way, become admired and acknowledged, has to be understood on the background of China's recent history. It partly explains the extreme support and enthusiasm from the ordinary Chinese as well as from the government.

China has experienced decades of humiliation since the "opium war" in 1840, and the aggrieved strain of Chinese nationalism has, according to Shambaugh (2008), deep roots back to the indignities foisted on China by European colonial powers, American missionaries, and Japanese invaders in the mid-20th centuries (with traumatic events such as the 1937-1938 "rape of Nanjing"), a period referred in Chinese textbooks today as 'the century of shame and humiliation'. The international community needs to understand the depth of this historical experience and sentiment in Chinese society and collective psyche. "It represents the raison d'être of the modern Chinese Communist state, which came to power on a promise to unify the nation, restore its dignity and never again permit foreigners to subjugate, discriminate against or try to 'split' China" (Shambough, 2008).

To repair the humiliation of China has powered the Chinese to be eager to show the rest of the world its capacities and qualities. The "determination to restore China's national grandeur" (Garver, 1993) has therefore been an important issue in China's vision of itself toward the outside world. This position, also named "pragmatic nationalism" (Garver, 1993), is not controversial in China and it is supported by most people.

At the same time, the Chinese Government is also eager to emphasize the national interest as something that needs to be strengthened. Hosting the Olympic Games is therefore also an instrument for developing and expressing this kind of nationalism or pride to be a Chinese. There is no hostility toward other nations or people in this kind of nationalism (perhaps except for the sensitive relationship to Japan).

What the respondents pay most attention to illustrates also that the Olympic Games is looked upon not first and foremost as a sports competition. The Olympic Games, as other mega sports events, has become instruments for other purposes than being competitions between athletes. Olympic Games has become a cultural exhibition and a media event with a main goal of promoting the host as a prosperous society.

Zhou (2008) and Zhou \& Ap (2009), who have examined the Beijing perception toward BOG using a 20-item impact scale with four factors, confirm the results in our study. The great majority of the residents $(96 \%)$ have a high level of enthusiasm and support for the Games and they also perceived the impacts of the BOG very positively. Especially, as in our study, the possibility of enhancing China's international reputation through world media exposure ( $95.5 \%$ of Beijing residents expected this to be an outcome of the BOG) will "give Beijing a chance to show what it is capable of" (92.4\% agree), and will "increase the pride of local residents" (93.2\% agree) (Zhou \& Ap, 2009).

\subsection{Former Olympic Games}

Using the Olympic Games to promote international reputation and national identity in the host country did not begin with the BOG. It has been an aim in most Olympic Games. The Athens 2004 Olympics, for instance, was staged to be a catalyst in changing the image of the country abroad and also enhancing the national pride (Karakatsoulis, Michalopoulus, \& Moustakatou, 2005). The "ideological-vision" of the Games was shared by the Greece people and it was "the joy, the passion, the easygoing skill of the Greeks," in other words, "the irresistible Hellenic flavour" (Powers, 2004) that made this Olympics successful. We see similarities with the Beijing 2008 Olympics.

Also, during the Sydney Olympics in 2000, the sense of community and pride inspired by the Olympic Spirit increased significant (Waitt, 2003). The results from BOG are therefore consistent with previous studies that other hosting Olympic Games countries have done. The results also are consistent with the situation in collectivistic or interdependent cultures, the inhabitants are more concerned about their motherland and their countrymen than on themselves as an individual.

\subsection{The Focus in Different Age/Cohort Groups}

The focus and expectations toward the BOG were clearly differentiated by respondents' age/cohort. Compared with the older respondents, the young respondents emphasized more opportunities to make money and improve their personal abilities, that is, to strengthen themselves and their personal identity. The younger generation was born after 1970, and grew up after the reform and opening-up policy (1979). The younger generation is expected to be more influenced by Western individualistic values and ideologies. The older generation was born before the founding of new China, the People's Republic of China. The older generation is more influenced by the history of modern China than the younger, and has more expectation to improve China's international reputation and get 
the national development by BOG.

\subsection{Concluding Remarks}

This study has shown that enhancing China's international reputation and improving the Chinese national identity were major driving forces behind the host city residents' enthusiasm for the Beijing 2008 Games, as it has been for host city populations in former Games. To raise the motherlands' status and improve national identity are two sides of a coin: the one follows from the other.

National identity is enriching national pride and, consequently, pride strongly motivates people to support and promote their country. What is good for China is good for its population, even if it did not give private benefits in terms of, for instance, improved economic conditions. The Chinese are modest, humble, and unassuming, and they have the ability to become happy on behalf of their country if it is evaluated as a successful and able nation.

\section{References}

Calgary Report. (1988). XVth Olympic Winter Games: Final Olympic Report. City of Calgary, Calgary.

Cashman, R. (2006). The bitter-sweet awakening: The legacy of the Sydney 2000 Olympic Games. Petersham, NSW, Australia: Walla Walla Press.

Colley, L. (1992). Britons: Forging the Nation 1707-1837. Yale University Press, New Haven, CT.

Evans, M. D. R., \& Kelley, J. (2002). National pride in the developed world: Survey data from 24 nations. International Journal of Public Opinion Research, 14(3), 303-338. http://dx.doi.org/10.1093/ijpor/14.3.303

Garver, J. W. (1993). Foreign relations of the People's Republic of China. Prentice Hall, Englewood Cliffs, NJ.

Hargreaves, J., \& Ferrando, M. G. (1997). Public opinion, national integration and national identity in Spain: The case of the Barcelona Olympic Games. Nations and Nationalism, 3(1), 65-87. http://dx.doi.org/10.1111/j.1354-5078.1997.00065.x

Hobsbawm, E. J. (1990). Nations and Nationalism since 1780. Cambridge University Press, Cambridge.

Houlihan, B. (1997). Sport, National Identity and Public Policy. Nations and Nationalism, 3(1), 113-137. http://dx.doi.org/10.1111/j.1354-5078.1997.00113.x

Ikhioya, O. S. (2001). Olympic Games as instruments in fostering national identities. Journal of the International Council for Health, Physical Education, Recreation, Sport \& Dance, 37(1), 14-17.

IOC. (2001). Report of the IOC evaluation commission for the Games of the XXIX Olympiad in 2008. Lausanne, Switzerland: IOC.

Johnston, F. (1985). The economic impacts of the XVth Olympic Winter Games. Travel and Tourism Research Association Proceedings (Canada Chapter), 82-105. Alberta.

Karkatsoulis, P., Michalopoulos, N., \& Moustakatou, V. (2005). The national identity as a motivational factor for better performance in the public sector: The case of the volunteers of the Athens 2004 Olympic Games. International Journal of production and Performance Management, 54(7), 579-594.

Kolstad, A. (1995). (19XX) Lillehammer OL's bidrag til nasjonalisme og etnosentrisme [The Lillehammer 1992 Olympic Games and its contribution to nationalism and ethnocentrism] Lillehammer, ØF-rapport, 07/1995.

Maguire, J. (1993). Globalisation, sport and national identities: "the Empires Strike Back"? Society \& Leisure, 16(2), 293-321.

Matthew, C. S. J., Stanley, G. Y. M., \& Kiat, L. T. (2000). An in-depth evaluation of survey on national pride and citizens' psychological ties to the nation. Straits Times, Institute of Policy Studies (IPS), 19 February. Retrieved from http://www.scholars.nus.edu.sg/quantitative/students/sample2.html

Powers, J. (2004, August 30). Greece was game: defying skeptics, undaunted nation delivers a winner. Boston Globe.

Ritchie, J. B., \& Lyons, M. (1990). Olympulse VI: A post-event assessment of residents' reaction to the XV Olympic Winter Games. Journal of Travel Research, 28(3), 14-23. http://dx.doi.org/10.1177/004728759002800303

Shambaugh, D. (2008, May 5). China's competing nationalisms. New York Times.

Singh, N., \& Hu, C. (2008). Understanding strategic alignment for destination marketing and the 2004 Athens Olympic Games: Implications from extracted tacit knowledge. Tourism Management, 29(5), 929-939. http://dx.doi.org/10.1016/j.tourman.2007.11.005 
Smith, T. W., \& Jarkko, L. (1998). National pride: a cross-national analysis. GSS, Report no. 19, NORC, University of Chicago, Chicago, IL.

Tang, Y. (2001, August 2). Beijing creates history. Beijing Review, 12-16.

Triandis, H. C. (1993). Collectivism and individualism as cultural syndromes. Cross-Cultural Research, 27(3-4), 155-180. http://dx.doi.org/10.1177/106939719302700301

Verba, S. (1965). Conclusion: comparative political culture. In L.W. Pye, \& S. Verba (Eds.), Political Culture and Political Development. Princeton University Press, Princeton, NJ.

Waitt, G. (2003). Social impacts of the Sydney Olympics. Annals of Tourism Research, 30(1), 194-215. http://dx.doi.org/10.1016/S0160-7383(02)00050-6

Xin, X. (2006). Modernizing China in the Olympic spotlight: China's national identity and the 2008 Beijing Olympiad. Journal of Sociological Review, 54, 90-107. http://dx.doi.org/10.1111/j.1467-954X.2006.00655.x

Yang, Y., Chen, M., Chen, W., Ying, X., Wang, B., Wang, J., \& Kolstad, A. (2010). Effects of boundary-permeated self and patriotism on social participation in the Beijing Olympic Games. Asian Journal of Social Psychology, 12(4), 274-284.

Zhou, J. Y. (2008). Government and residents' perceptions towards the impacts of a mega event: The Beijing 2008 Olympic Games. Dissertation Abstracts International Section A: Humanities and Social Sciences, 68(9-A), 3963.

Zhou, Y., \& Ap, J. (2009). Residents' Perceptions towards the Impacts of the Beijing 2008 Olympic Games. Journal of Travel Research, 48(1), 78-91. http://dx.doi.org/10.1177/0047287508328792

\section{Copyrights}

Copyright for this article is retained by the author(s), with first publication rights granted to the journal.

This is an open-access article distributed under the terms and conditions of the Creative Commons Attribution license (http://creativecommons.org/licenses/by/3.0/). 